\title{
Duration of protective immunity after a single vaccination with a live attenuated bivalent bluetongue vaccine
}

\author{
Kuandyk Zhugunissov $^{1}$ - Zakir Yershebulov ${ }^{1}$ - Kainar Barakbayev ${ }^{1} \cdot$ Yerbol Bulatov $^{1}$. \\ Dmitriy Taranov ${ }^{1} \cdot$ Zhanat Amanova $^{1} \cdot$ Yergali Abduraimov $^{1}$
}

Received: 3 June 2015 / Accepted: 11 August 2015 /Published online: 18 August 2015

(C) The Author(s) 2015. This article is published with open access at Springerlink.com

\begin{abstract}
The prevention of bluetongue is typically achieved with mono- or polyvalent modified- live-attenuated virus (MLV) vaccines. MLV vaccines typically elicit a strong antibody response that correlates directly with their ability to replicate in the vaccinated animal. They are inexpensive, stimulate protective immunity after a single inoculation, and have been proven effective in preventing clinical bluetongue disease. In this study, we evaluated the safety, immunogenicity, and efficacy of a bluetongue vaccine against Bluetongue virus serotypes 4 and 16 in sheep. All the animals remained clinically healthy during the observation period. The vaccinated animals showed no clinical signs except fever $\left(>40.8^{\circ} \mathrm{C}\right)$ for 2-4 days. Rapid seroconversion was observed in the sheep, with the accumulation of high antibody titers in the vaccinated animals. No animal became ill after the challenge, indicating that effective protection was achieved. Therefore, this vaccine, prepared from attenuated bluetongue virus strains, is safe, immunogenic, and efficacious.
\end{abstract}

Keywords Bluetongue $\cdot$ Vaccine $\cdot$ Safety $\cdot$ Immunogenicity

\section{Introduction}

Bluetongue is a viral disease transmitted by Culicoides spp. Infection is characterized by fever, congestion, edema, hemorrhage, hyperemia and ulceration of the oral mucosa, coronitis, and lameness in domestic and wild ruminants

Kuandyk Zhugunissov

kuandyk_83@mail.ru

1 Research Institute for Biological Safety Problems, Gvardeiskiy, Kordai Raion 080409, Zhambyl Oblast, Republic of Kazakhstan
(Roy 2002). Bluetongue virus (BTV) belongs to the family Reoviridae and is the type species of the genus Orbivirus, which also includes the epizootic hemorrhagic disease virus of deer and African horse sickness virus. BTV has a high level of antigenic variation, with 27 serotypes recognized worldwide (Jenckel et al. 2015).

Bluetongue was first described in Africa at the beginning of the 20th century and was considered exotic in Europe before1998. Since then, at least six serotypes (BTV-1, -2, $-4,-8,-9$, and -16) have invaded the European mainland on different occasions (Bréard et al. 2011), with a recent epizootic outbreak. The disease is mainly spread through trading of breeding animals from bluetongue-enzootic countries (Murueva 2011). According to data from the Ministry of Agriculture of the Republic of Kazakhstan on beef imports, over 50,000 head of cattle were delivered to Kazakhstan from the United States, Czech Republic, Canada, Russia, Ukraine, France, Australia, Ireland, Austria, and Germany in 20112014 (http://kapital.kz/economic/30953/rk-ogranichit-importkrupnogo-rogatogo-skota.html). Importation creates a risk of the emergence of bluetongue because many of these countries have enzootic bluetongue infections (OIE, Terrestrial Animal Health Code 2011). Over the past 15 years, Kazakhstan has conducted no serosurveys to monitor BTV infection, although neighboring countries contain seropositive animals (Zhugunisov et al. 2009; Vishnyakov et al. 1995) and have isolated different serotypes of BTV (Avci et al. 2014; Yang et al. 2011; Yang et al. 2012). Moreover, Lundervold et al. (2004) found BTV circulating in Kazakhstan among ruminants more than 10 years ago. Therefore, Kazakhstan is at an unknown, but significant, risk of bluetongue.

Bluetongue is typically prevented with mono- and polyvalent modified live virus (MLV) vaccines, inactivated (killed) virus vaccines, virus-like particles produced from recombinant baculoviruses, or recombinant Vaccinia- or -Canarypox 
virus-vectored vaccines (Savini et al. 2008; Noad and Roy 2009). MLV vaccines typically elicit a strong antibody response, which correlates directly with their ability to replicate in the vaccinated animal. The vaccines are inexpensive, stimulate protective immunity after a single inoculation, and have been proven effective in preventing clinical disease (Savini et al. 2008; Patta et al. 2004).

Given the recent spread of bluetongue to areas around Kazakhstan and worldwide, there is significant interest in developing an efficacious and safe vaccine against BTV serotypes 4 and 16, because these are most prevalent in the areas surrounding Kazakhstan. No information is currently available on the duration of the protective properties of live-attenuated vaccines against bluetongue. Therefore, in this study, we undertook developing and testing of an attenuated bivalent vaccine against BTV, and examining the protection it confers after a single immunization.

\section{Materials and methods}

\section{Viral strains}

We used the BTV strains Khuroson-40/13/4 (BTV-4) and RT/ RIBSP40/13/16 (BTV-16) (Sametova et al. 2013), which were obtained in lyophilized form from the laboratory of the "Collection of Microorganisms" at the Research Institute for Biological Safety Problems (RIBSP) and refreshed in Vero cells. Both strains were isolated individually by serial passages in chicken embryos (to passage 40), then in Vero cell culture (passage 10). To determine the reversion of the attenuated viruses, the viral material was passaged in mice (1-3 days of age) and sheep (6-12 months of age). The sheep and mice remained alive, with no clinical signs of infection for 30 days. Both animal models, which are commonly used to evaluate the attenuation of BTV, are sufficient to test the attenuated strains (Franchi et al. 2008). By this work, the results of the study are presented in detail in a previously published paper (Sametova et al. 2013). We have also obtained patents for strains Khuroson-40/13/4 (patent \#2013/1344.1) and RT/RIBSP40/13/16 (patent \#2013/1345.1) (https://gosreestr. kazpatent.kz/ru/Search\%20Patent). The viral material was titrated in Vero cell cultures, and the viral titers were expressed in $\log _{10}$ tissue culture infective doses (TCID) $)_{50} /$ $\mathrm{mL}$, calculated with the method of Reed and Muench (1938).

\section{Animals and bioethics}

A total of 288 3-6-month-old female Kazakh fat-tailed sheep were used in this study. The sheep for the experiments were kept in quarantine for 1 month holding thermometry, after a clinical examination and blood serum test for the presence of specific antibodies, with a competitive enzyme-linked immunosorbent assay (cELISA; ID-Screen Bluetongue Early detection ELISA, ID-Vet, Montpellier, France). All the sheep were healthy and seronegative for BTV 3 days before the first vaccination. The animals were randomly allocated to the vaccinated and unvaccinated groups. Each group was kept in a separate room and had free access to water and feed throughout the experiment. This study was performed in compliance with national and international laws and guidelines on animal handling, and the experimental protocol was approved by the Committee on the Ethics of Animal Experiments of the RIBSP of the Science Committee of the Ministry of Education and Science of the Republic of Kazakhstan (permit number: 0114/100).

\section{Preparation of the bivalent BTV vaccine}

Each viral suspension (Khuroson-40/13/4 and RT/RIBSP40/ $13 / 16$ vaccine strains) was clarified by centrifugation at $3000 \times g$ for $30 \mathrm{~min}$. Viral suspension was then combined with a stabilizing medium (at a final concentration of $3 \%$ peptone [Sigma-Aldrich, St. Louis, MO, USA] and $2 \%$ lactose [Sigma-Aldrich]) in a ratio of 1:1. A total of 200,000 units of penicillin, $200 \mathrm{mg}$ of streptomycin, and 5000 units of nystatin were added to the suspension, the volume was expanded to $1 \mathrm{~L}$, and the solution was refrigerated at $4{ }^{\circ} \mathrm{C}$ for $10-12 \mathrm{~h}$. The liquid was then divided into aliquots in $1 \mathrm{~mL}$ ampoules and lyophilized for storage.

\section{Vaccine safety}

The safety ofvaccine was tested by injecting it subcutaneously to nine sheep at a dose of $10^{6} \mathrm{TCID}_{50} / \mathrm{mL}$. The paired control group was administered $1 \mathrm{~mL}$ of subcutaneous phosphate-buffered saline (PBS). After vaccination, the body temperatures of the sheep were checked daily and their clinical signs were monitored for 14 days. The animals that showed severe clinical signs (loss of more than $20 \%$ body weight, frequent hunching, severe conjunctivitis, or any condition that prevented food or water intake) were euthanized.

\section{Testing for reversion of the vaccine to wild type}

We used 30 seronegative sheep to test the seroconversion of the vaccine. The sheep were divided into 10 groups of three animals. The first group was administered the vaccine intravenously at a dose of $10^{4} \mathrm{TCID}_{50} / \mathrm{mL}$. To detect viremia 7 8 days after viral inoculation, blood samples were collected from the febrile animals in ethylenediaminetetraacetic acid. The blood samples were pooled and titrated in Vero cell cultures. The inoculum $(10-\mathrm{mL})$ was administered to the second group of three seronegative sheep. Further testing was performed similarly with all 10 passages in three replicates each. 
The animals were observed as described above, for approximately 3 weeks, to evaluate their health status and viremia.

\section{Vaccine administration}

Two hundred forty female sheep were inoculated subcutaneously with a single dose $\left(10^{4} \mathrm{TCID}_{50} \mathrm{~mL}\right)$ of vaccine. During the vaccination phase, the sheep were housed indoors in pens and their health status monitored (rectal temperature and clinical signs) for 1 year. Blood samples were taken by jugular venipuncture at regular intervals (days 7, 14, 21, 28, 90, 180, 270, and 360 post-vaccination). The sera were tested for antibody titers with the serum neutralization test (SNT) and ELISAs.

\section{Challenge study}

Virulent strains BTV4 and BTV16 $\left(5.5 \mathrm{LD}_{50} / \mathrm{mL}\right.$ for BTV4 and BTV16) were used to challenge the sheep. These BTV strains were isolated from sheep in the Republic of Tajikistan during monitoring research by the employees of the RIBSP in 2007 (Abduraimov et al. 2009). Both BTV types were plaque purified three times in Vero cells and their type specificity was verified with a microneutralization test. The strains had been passaged three times in sheep. The challenge material consisted of blood samples collected from BTV4- and BTV16-infected animals, which were lyophilized and submitted to the RIBSP collection of microorganisms. We used three vials of control BTV4 and BTV16 strains for the challenge. All the vials were opened vials with dried blood, dissolved in PBS, and pooled, separately. The vaccinated sheep (described above) were intravenously administered $10 \mathrm{~mL}$ of homologous virulent strains $\left(5.5 \log _{10} \mathrm{ELD}_{50} / \mathrm{ml}\right.$ for BTV4 and BTV16). The animals were observed for 30 days with daily measurements of body temperature, and were evaluated for clinical signs with a scoring system (Table 1). Vaccine immunogenicity was evaluated by comparing the reactions of the vaccinated and unvaccinated sheep to infectious challenge. The control sheep should score at least 10 points after infection. A difference between the vaccinated and unvaccinated sheep was considered insignificant if the average difference in the scores was $0-7$ points, weak if the difference was 7-12 points, moderate if the difference was $12-16$ points, and pronounced if the difference was $>16$ points (Sergeev et al. 1981).

\section{Group-specific ELISAs}

The BTV-specific antibodies in the sheep sera were detected with a competitive ELISA (cELISA, ID-Screen Bluetongue Early detection ELISA, ID-Vet, Montpellier, France) directed against VP7, according to the manufacturer's instructions. For this study, a threshold value of $40 \%$ negativity (PN) was used to discriminate between positive $(\mathrm{PN}<40)$ and negative $(\mathrm{PN} \geq 40)$ BTV ELISA results.
Table 1 Assessment of clinical signs of bluetongue in sheep

\begin{tabular}{|c|c|c|}
\hline Category & Clinical sign & Score \\
\hline \multirow{4}{*}{$\begin{array}{l}\text { Fever (temperature } 40.1^{\circ} \mathrm{C} \\
\text { and higher) }\end{array}$} & $1-3$ days with a peak of up to $41^{\circ} \mathrm{C}$ & 1 \\
\hline & $\begin{array}{l}1-3 \text { days with a peak greater than } \\
41^{\circ} \mathrm{C}\end{array}$ & 2 \\
\hline & $\begin{array}{l}4 \text { or more days with a peak of } \\
\text { up to } 41^{\circ} \mathrm{C}\end{array}$ & 3 \\
\hline & $\begin{array}{l}4 \text { or more days with a peak greater } \\
\text { than } 41^{\circ} \mathrm{C}\end{array}$ & 4 \\
\hline \multirow{3}{*}{$\begin{array}{l}\text { Mucous membranes } \\
\quad \text { (eyes, nose, mouth) }\end{array}$} & Mild hyperemia & 1 \\
\hline & Severe hyperemia & 2 \\
\hline & Cyanosis & 3 \\
\hline \multirow[t]{3}{*}{ Cervical swelling } & Mild swelling of the eyelids or lips & 1 \\
\hline & $\begin{array}{l}\text { Obvious swelling of the eyelids } \\
\text { or lips }\end{array}$ & 3 \\
\hline & Swollen muzzle & 4 \\
\hline Erosion or hemorrhage & $\begin{array}{l}\text { Erosions in the oral and nasal } \\
\text { cavities or hemorrhages on the } \\
\text { nares or nasal planum }\end{array}$ & 3 \\
\hline \multirow[t]{3}{*}{ Keratitis } & Focal unilateral keratitis & 2 \\
\hline & $\begin{array}{l}\text { Diffuse unilateral or multifocal } \\
\text { bilateral keratitis }\end{array}$ & 3 \\
\hline & Diffuse bilateral keratitis & 4 \\
\hline \multirow[t]{3}{*}{ Attitude } & Mildly depressed & 1 \\
\hline & Moderately depressed & 2 \\
\hline & Severely depressed with anorexia & 3 \\
\hline \multirow[t]{2}{*}{ Muscle weakness } & Mild & 1 \\
\hline & $\begin{array}{l}\text { Pronounced, with or without } \\
\text { lameness }\end{array}$ & 2 \\
\hline Lacrimation & & 1 \\
\hline \multirow[t]{2}{*}{ Nasal secretions } & Mucous & 1 \\
\hline & Purulent & 2 \\
\hline Sialorrhea & Sialorrhea or foaming at the mouth & 1 \\
\hline Diarrhea & & 1 \\
\hline \multirow[t]{2}{*}{ Body condition } & Decreased body condition & 1 \\
\hline & Emaciation & 2 \\
\hline Maximum score & & 30 \\
\hline
\end{tabular}

\section{Detection of neutralizing antibody response in the sera of vaccinated animals}

SNT was performed according to the method of Haig and MaRAA (1956) using the BTV-4 and BTV-16 reference strains and serotype-specific BTV-4 and BTV-16-positive control antisera. Briefly, the sheep sera were diluted (1:2 to 1:128) and titrated against $100 \mathrm{TCID}_{50}$ of the BTV-4 vaccine strain. BTV16 was analyzed separately, in a similar way. The plates were incubated for $1 \mathrm{~h}$ at $37{ }^{\circ} \mathrm{C}$, and then maintained at $4{ }^{\circ} \mathrm{C}$ overnight. The following day, $50 \mu \mathrm{L}$ of a Vero cell suspension $\left(2 \times 10^{5}\right.$ cells $\left./ \mathrm{mL}\right)$ was added to each well, and the plates were incubated for $4-7$ days at $37^{\circ} \mathrm{C}$. The wells were then scored for a cytopathic effect. The neutralization titer was determined as the dilution of serum giving a $50 \%$ neutralization end point. 


\section{Statistical analysis}

All statistical analyses were performed with GraphPad Prism ${ }^{\circledR}$ version 6.0. Two-way analysis of variance was used to compare the rectal temperatures, clinical scores, and serology of the groups, with $P \leq 0.05$ considered statistically significant.

\section{Results}

\section{Safety of test series of the bivalent live cultural vaccine against BTV}

Other than a relatively mild fever $\left(40.3-40.8^{\circ} \mathrm{C}\right)$ for $2-4$ days and swelling at the site of vaccination which resolved within 2-3 days, the animals developed no clinical signs after vaccination (Table 2). These results indicate that this vaccine is generally safe for sheep.

\section{Reversion to virulence}

Both strains induced viremia in susceptible animals (Fig. 1). During the passages in sheep, the BTV titer was $1.16 \pm 0.16$ $\log _{10} \mathrm{TCID}_{50} / \mathrm{mL}$ at the first passage, decreasing to $0.83 \pm 0.08$ and $0.92 \pm 0.08 \log _{10} \mathrm{TCID}_{50} / \mathrm{mL}$ with subsequent passages $(P \leq 0.001)$ (10 total).

The attenuated virus showed no pathogenic properties after its intravenous administration to sheep, and all the animals remained healthy during the observation period (30 days).

\section{Neutralizing antibody titers}

One week after vaccination, all the sheep had detectable levels of neutralizing antibodies, measured with a SNT, with mean

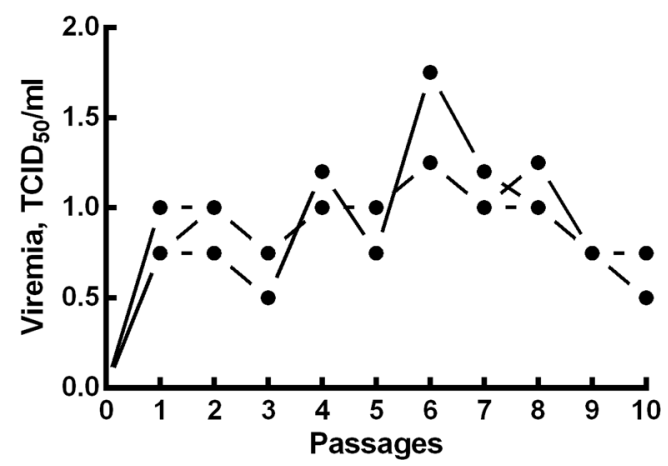

Fig. 1 Viral titers during passage. We used 30 seronegative sheep in the experiment. The sheep were divided into 10 groups of three animals. The first group was administered the vaccine intravenously at a dose of $10^{4}$ $\mathrm{TCID}_{50} / \mathrm{mL}$. To determine the level of viremia 7-8 days after viral inoculation, blood samples were collected from the febrile animals in ethylenediaminetetraacetic acid and titrated in Vero cell culture. The inoculum $(10-\mathrm{mL})$ was administered to the second group of three sheep. Further testing was performed similarly in triplicate after each of the 10 passages

titers $\left(\log _{10}\right)$ ranging from 1.1 (for BTV-4) to 1.25 (for BTV16) at 7 days after-vaccination (Fig. 2). Four weeks after vaccination, all the vaccinated animals had even higher levels of neutralizing antibodies: $4.0-4.8 \log _{2}$ at 28 days and 1.8-2.0 $\log _{2}$ at 360 days (Fig. 2).

The levels of NA in the sera of the immunized sheep differed significantly for both serotypes from day 7 to day 360 $(P \leq 0.0001)$.

\section{Group-specific antibody titers}

A graphical summary of the percentage inhibition (IP) results are given for each group in Fig. 3. All sheep were seronegative before vaccination and the control sheep remained seronegative in all assays until challenge. After vaccination, the percentage inhibition

Table 2 Vaccine safety

\begin{tabular}{|c|c|c|c|c|c|c|c|c|c|c|}
\hline \multirow[t]{2}{*}{ Inoculum } & \multirow{2}{*}{$\begin{array}{l}\text { Animal } \\
\text { number }\end{array}$} & \multirow{2}{*}{$\begin{array}{l}\text { Viral dose } \\
\left(\text { TCID }_{50} / \mathrm{mL}\right) / \\
\text { volume }\end{array}$} & \multicolumn{8}{|c|}{ Clinical signs or reaction of animals } \\
\hline & & & Swelling & Fever & Stomatitis & Diarrhea & Conjunctivitis & Nasal secretions & Sialorrhea & Depletion \\
\hline \multirow{9}{*}{$\begin{array}{l}\text { Live attenuated } \\
\text { bivalent vaccine }\end{array}$} & 134 & $1 \times 10^{6} / 1.0$ & + & + & - & - & - & - & - & - \\
\hline & 182 & $1 \times 10^{6} / 1.0$ & + & - & - & - & - & - & - & - \\
\hline & 163 & $1 \times 10^{6} / 1.0$ & + & + & - & - & - & - & - & - \\
\hline & 132 & $1 \times 10^{6} / 1.0$ & + & + & - & - & - & - & - & - \\
\hline & 336 & $1 \times 10^{6} / 1.0$ & + & - & - & - & - & - & - & - \\
\hline & 181 & $1 \times 10^{6} / 1.0$ & + & + & - & - & - & - & - & - \\
\hline & 178 & $1 \times 10^{6} / 1.0$ & + & + & - & - & - & - & - & - \\
\hline & 333 & $1 \times 10^{6} / 1.0$ & + & - & - & - & - & - & - & - \\
\hline & 192 & $1 \times 10^{6} / 1.0$ & + & + & - & - & - & - & - & - \\
\hline \multirow[t]{2}{*}{ PBS (control) } & 398 & $0 / 1.0$ & + & - & - & - & - & - & - & - \\
\hline & 353 & $0 / 1.0$ & + & - & - & - & - & - & - & - \\
\hline
\end{tabular}


Fig. 2 Dynamics of neutralizing antibodies in the vaccinated sheep. Data are means \pm standard errors; $* * * * P<0.0001$.

Neutralizing antibody titers were calculated with the Reed-Muench method and are expressed as $\log _{2}$ values

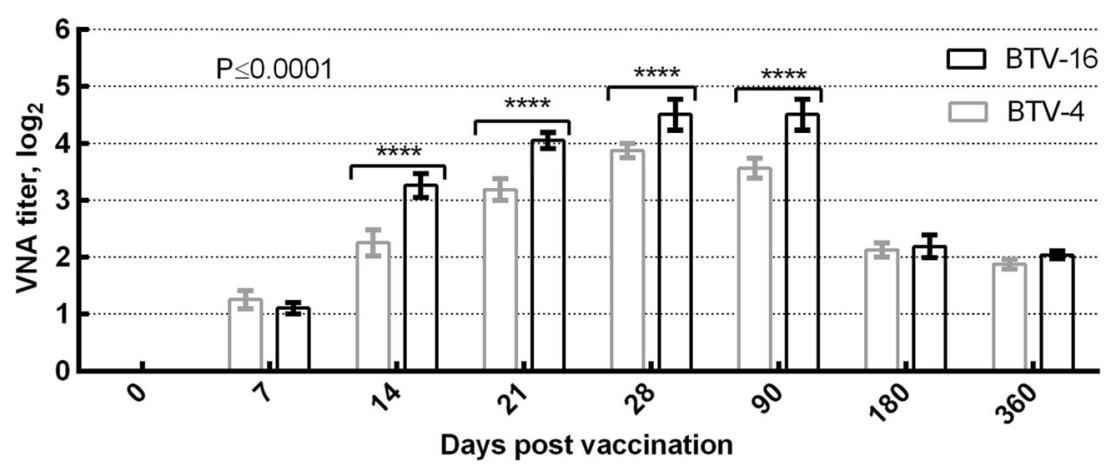

decreased dramatically. The optical densities of specific antibodies decreased throughout the duration of the study, from IP $<8 \pm 3.07$ at day 28 , to IP $<16.5 \pm 4.95$ at day 90 , and IP $<46.25 \pm 6.40$ at day 360 .

\section{Clinical protection following challenge}

Seven days after immunization, the animals developed protective immunity against BTV (Fig. 4a). However, the vaccinated animals were insufficiently protected from challenge because they developed clinical signs of bluetongue, with an average score of 10 points. The unvaccinated control animals also developed clinical signs, with an average score of 20.8 points, so the difference in the mean scores was 10.8 points. At 14, 90, and 270 days after immunization, strong protective responses developed against BTV-4 and BTV-16 (Fig. 4b, c). The vaccinated animals showed a slight increase in body temperature after challenge, whereas the unvaccinated animals developed typical clinical signs of the disease. At 360 days after immunization, one vaccinated sheep showed an increase in body temperature of $41.5{ }^{\circ} \mathrm{C}$ for 2 days after challenge, which then returned to normal (Fig. 4d). The vaccinated animals had an average clinical score of one point after challenge, whereas the unvaccinated animals had an average score of 27 points, indicating the high protective activity of the test vaccine.

\section{Discussion}

Infection with BTV is common in a broad band across the world, which until recently stretched from latitude $\sim 35^{\circ} \mathrm{S}$ to $40-50^{\circ} \mathrm{N}$. Since the $1990 \mathrm{~s}$, the range of BTV has extended considerably north of the 40th and even the 50th parallels in some parts of the world (Maan et al. 2007; Coetzee et al. 2012).

All attenuated BTV strains have pronounced reactogenic properties. These properties are characterized by the appearance in the vaccinated animal of a quite moderate to severe reaction temperature, between 6 and 10 days after vaccination. The response to the vaccine is followed by viremia. These phenomena are regarded as positive signs of infection, indicating the development of an immune response (Kercher et al. 1957).

One of the most important steps when preparing a liveattenuated vaccine is the assessment of its level of attenuation in the target animals (sheep and newborn mice). These models, which are used to evaluate the attenuation of BTV, are sufficient to test the attenuated strains (Franchi et al. 2008). Therefore, we determined the levels of attenuation of the BTV strains with 10 serial passages in sheep. We evaluated the reversion of the two vaccine strains by passaging them 10 times through susceptible sheep, and thus showed that the pathogenicity of these attenuated strains was not restored. However, these strains replicated in the sheep and could be isolated from the blood of the animals $2-12$ days after vaccination.
Fig. 3 Evolution of mean percentage inhibition s (with standard deviation) in each group of vaccinated and control sheep during the experiment after a single vaccination. (anti-VP7 antibody ELISA)

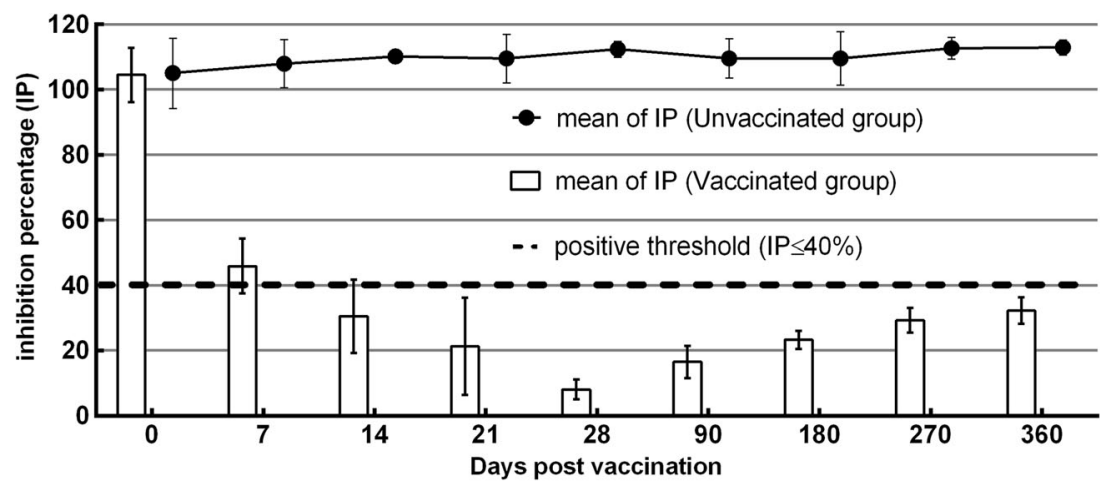



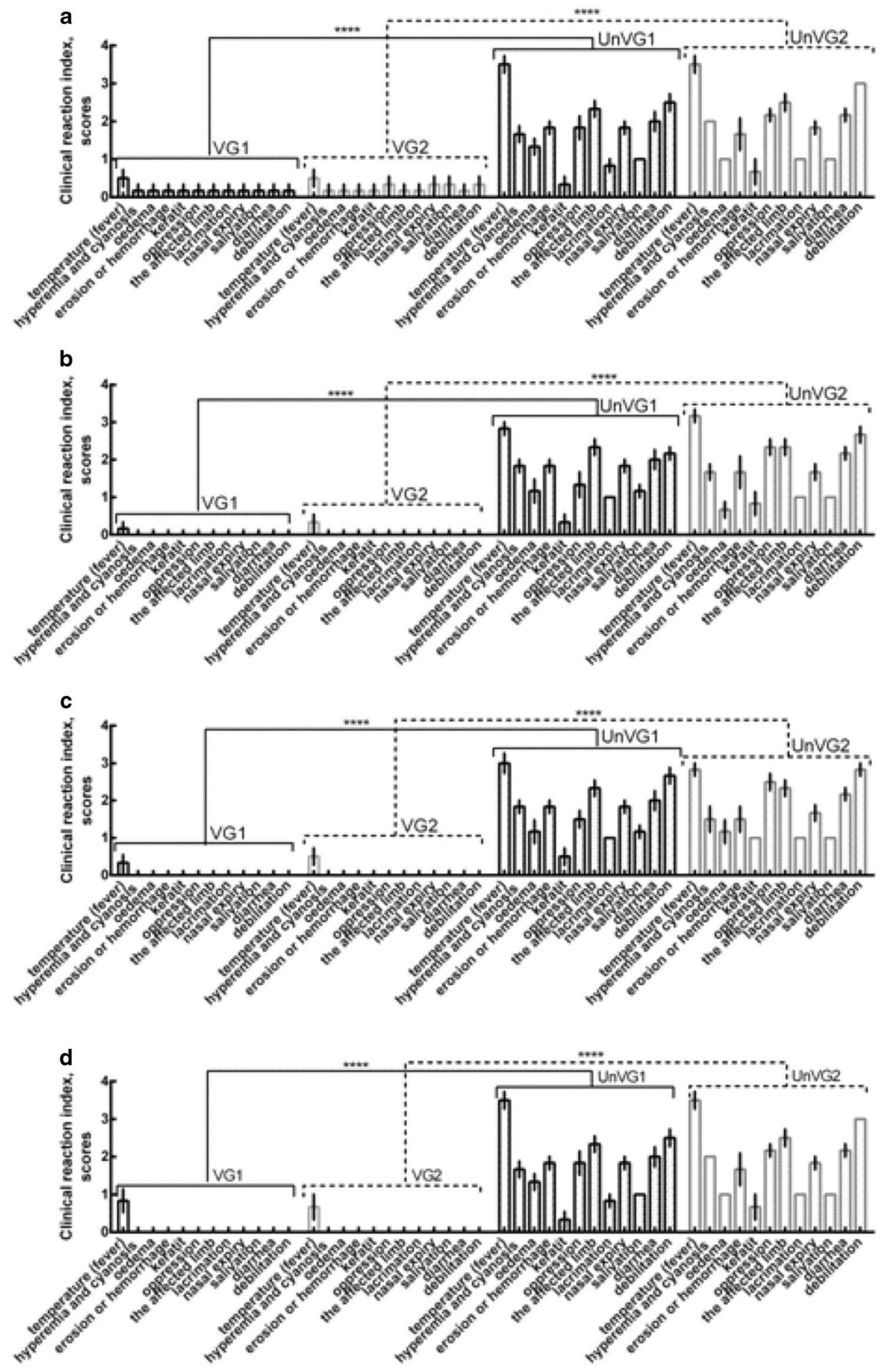
Fig. 4 Assessment of the clinical signs in immunized sheep after infection with virulent BTV. a Challenge 7 days after vaccination. b Challenge 90 days after vaccination. c Challenge 270 days after vaccination. d Challenge 360 days after vaccination. $V G 1$ vaccinated group infected with virulent BTV-4. $(n=30) V G 2$ vaccinated group infected with virulent BTV-16. $(n=30)$. UnVG1 unvaccinated group infected with virulent BTV-4. $(n=4)$. UnVG2 unvaccinated group infected with virulent BTV-16. $(n=4)$. Data are means \pm standard errors; $* * * * P<0.0001$

The MLV vaccine administered at doses not exceeding 2.0 $\log _{10} \mathrm{TCID}_{50} / \mathrm{mL}$, produced long-lasting viremia in the sheep, whereas virulent strains accumulated in the blood at levels up to $5.50 \log _{10} \mathrm{TCID}_{50} / \mathrm{mL}$. Although this viremia makes the MLV more immunogenic, because it continues to producing an immune response long after the initial injection, the possibility of reversion to virulence cannot be ruled out given the limitations of the present study. In particular, previous research has shown that the virus can revert to virulence after infecting its natural vectors (Batten et al. 2008). In this case, the viremia produced by the vaccine strain persisted longer than that induced by the pathogenic strains. Vaccination with MLV and inactivated viruses produces neutralizing and groupspecific antibodies (Oura et al. 2009; Hamers et al. 2009) protecting the vaccinated animal against challenge. Liveattenuated vaccines usually elicit a strong immune response, with the development of antibodies, and are usually efficacious after a single dose (Patta et al. 2004; Dungu et al. 2008).

Neutralizing antibodies have been shown to be an essential component of the protective immune response against BTV (Huismans et al. 1987; Roy et al. 1990) and similar titers, (1.5-2.5 $\log _{2}$ ) have been observed after vaccination with killed commercial vaccines in ruminants, which were ultimately protected from BTV-8 challenge (Bréard et al. 2011). Our experimental data are consistent with those of other researchers. Therefore, we have established that 7 days after vaccination with the attenuated vaccine, virus-neutralizing antibodies to BTV are present in the sera at a titers of $1.0 \log _{2}$. This antibody titer is protective against the homologous virulent strain of BTV. Although further research isrequired, particularly regarding the safety of the vaccine in pregnant sheep, this bivalent vaccine has been shown to be safe and efficacious, and will be a valuable tool in preventing the spread of bluetongue to Kazakhstan.

\section{Conclusions}

In conclusion, in an efficacy study, a single dose of an attenuated bivalent vaccine directed against BTV-4 and BTV-16 provided solid clinical protection against experimental challenge for 12 months. There was a strong anamnestic response in the vaccinated sheep and a good correlation between the neutralizing antibodies at the time of challenge and the protection afforded against both viral replication and clinical disease.

Acknowledgments The authors express their deep gratitude to the head of the laboratory, Dr. Z.K. Koshemetov, senior researcher Z.B. Kondibaeva, and senior laboratory assistant Z.Z. Sametova for carrying out the research. We also wish to thank the head of the laboratory, Dr. K.K. Tabynov, for his assistance the research design.

The work was performed within the scientific project (state registration \#0112 RK00306) on grant financing for 2012-2014 with the assistance of the Committee of Science of the Ministry of Education and Science of the Republic of Kazakhstan.

Conflict of interest The authors declare that they have no conflicts of interest.

Open Access This article is distributed under the terms of the Creative Commons Attribution 4.0 International License (http:// creativecommons.org/licenses/by/4.0/), which permits unrestricted use, distribution, and reproduction in any medium, provided you give appropriate credit to the original author(s) and the source, provide a link to the Creative Commons license, and indicate if changes were made.

\section{References}

Abduraimov YeO, Ramankulov YeM, Mamadaliev SM, Koshemetov ZhK, Yershebulov ZD (2009) The results of monitoring of bluetongue in Central Asia and Kazakhstan//Collected materials of the international scientific-practical conference "Prospects of cooperation of the Shanghai Cooperation Organization to counter the threat of infectious diseases" (May 14-15, 2009, Novosibirsk, Russia). Novosibirsk. 49-52. (In Russian)

Avci O, Orhan Y, Oya B, Mehmet K, Sibel Y, Atilla S (2014) Detection of antibodies against Blue tongue virus in yaks (Bos grunniens) in Issyk kul, first report. J Anim Plant Sci 24(4): 1220-1223

Batten CA, Maan S, Shaw AE, Maan NS, Mertens PP (2008) A European field strains of bluetongue virus derived from two parental vaccine strains by genome segment reassortment. Virus Res 137:56-63

Bréard E, Belbis G, Hamers C, Moulin V, Lilin T, Moreau F, Millemann Y, Montange C, Sailleau C, Durand B, Desprat A, Viarouge C, Hoffmann B, de Smit H, Goutebroze S, Hudelet P, Zientara S (2011) Evaluation of humoral response and protective efficacy of two inactivated vaccines against bluetongue virus after vaccination of goats. Vaccine 29(13):2495-2502

Coetzee P, Stokstad M, Venter EH, Myrmel M, Van Vuuren M (2012) Bluetongue: a historical and epidemiological perspective with the emphasis on South Africa. Virol J 9:198

Dungu BK, Louw I, Potgieter C, Von Teichman BF (2008) Attenuated live Bluetongue virus 8 vaccine protects sheep from challenge with the European BTV-8. Open Vet Sci J 2:130-133

Franchi P, Mercante MT, Ronchi GF, Armillotta G, Ulisse S, Molini U, Di Ventura M, Lelli R, Savini G, Pini A (2008) Laboratory tests for evaluating the level of attenuation of bluetongue virus. J Virol Methods 263-265

Haig DG, MaRAA DA (1956) The cytopathic action of Bluetongue virus on tissue cultures and its application to the detection of antibodies in the serum of sheep. Onderstepoort J Vet Res 27(2):171-177

Hamers C, Rehbein S, Hudelet P, Blanchet M, Lapostolle B, Cariou C, Duboeuf M, Goutebroze S (2009) Protective duration of immunity of an inactivated bluetongue (BTV) serotype 2 vaccine against a virulent BTV serotype 2 challenge in sheep. Vaccine 27:2789-2793 
Huismans H, Van Der Walt NT, Cloete M, Erasmus BJ (1987) Isolation of a capsid protein of bluetongue virus that induces a protective immune response in sheep. Virology 157(1):172-179

Jenckel M, Bréard E, Schulz C, Sailleau C, Viarouge C, Hoffmann B, Höper D, Beer M, Zientara S (2015) Complete coding genome sequence of putative novel bluetongue virus serotype 27 . Genome Announc 3(2):e00016-e00015. doi:10.1128/genomeA.00016-15

Kercher DG, Gowan B, Cabasso VJ, Roberts JK (1957) Saito. Studies on bluetongue 3 . The development of a modified live virus vaccine employing American strains of bluetongue virus. Am J Vet Res 18:310-316

Lundervold M, Milner-Gnlland EJ, O'Callaghan CJ, Hamblin CA, Corteyn AP, Macmillan A Serological survey of ruminant livestock in Kazakhstan during post-soviet transitions in farming and disease control. Actavet Scand, 2004; 45, 211-224

Maan S, Maan NS, Samuel AR, Rao S, Attoui H, Mertens PC (2007) Analysis and phylogenetic comparisons of full-length VP2 genes of the 24 bluetongue virus serotypes. J Gen Virol 88:621-630

Murueva GB (2011) The relevance of control of bluetongue of sheep at ensuring food security of the republic of Buryatia. Sheep Goats Wool Case 3:48-50 (In Russian)

Noad R, Roy P (2009) Bluetongue vaccines. Vaccine 27:86-89

OIE Terrestrial Animal health Code (2011) Volume I, General provisions Twentieth edition, pp:67-71

Oura CAL, Wood JLN, Sanders AJ, Bin-Tarif A, Henstock M, Edwards L, Floyd T, Simmons H, Batten CA (2009) Seroconversion, neutralising antibodies and protection in bluetongue serotype 8 vaccinated sheep. Vaccine 27:7326-7330

Patta C, Giovannini A, Rolesu S, Nannini D, Savini G, Calistri P, Santucci U, Caporale V (2004) Bluetongue vaccination in Europe: the Italian experience. Vet Ital 40:601-610
Reed IJ, Muench HA (1938) A simple method of estimating fifty per cent endpoints. Am J Hyd 27:493-497

Roy P (2002) Orbivirus. 1st Edn. In: Tidona CD, Darai G (eds) The Springer index of viruses. Springer-Verlag, Berlin, pp. 957-963

Roy P, Urakawa T, Van Dijk AA, Erasmus BJ (1990) Recombinant virus vaccine for bluetongue disease in sheep. J Virol 64(5):1998-2003

Sametova Zh, Yershebulov Z, Amanova Zh (2013) The principal possibility of attenuation strains of bluetongue. Materials of The International Scientific conference of Young Scientists dedicated to the 55th anniversary of the establishment of the Research Institute for Biological Safety Problems, Gvardeiskiy, 7 August, 2013; 172-181. (In Russian)

Savini G, MacLachlan NJ, Sanchez-Vizcaino JM, Zientara S (2008) Vaccines against bluetongue in Europe. Comp Immunol Microbiol Infect Dis 31:101-120

Sergeev VA, Vasilenko NZ, Valiashvili GG, Alloyarova GM, AnanevaRyashchenko NP, Peresadkin SI, Kosheleva RV (1981) Reactogenic and immunogenic properties of the polio vaccine against bluetongue. Materials of scientific and theoretical conference, March 16-18, ARRIVVaM, 97-99. (In Russian)

Yang T, Liu N, Xu Q, Sun E, Qin Y, Zhao J, Wu D (2011) Complete genomic sequence of bluetongue virus serotype 16 from China. J Virol 85:13472

Yang T, Liu N, Xu Q, Sun E, Qin Y, Zhao J, Feng Y, Wu D (2012) Complete genomic sequence of bluetongue virus serotype 1 from China. J Virol 86(2):1288

Vishnyakov IF, Novikov MB, Strizhakov AA (1995) Identification and typing of bluetongue virus. Vet Med 4:20-25(In Russian)

Zhugunisov KD, Abduraimov YO, Mamadaliyev SM (2009) Bluetongue of sheep is a new danger for Kazakhstan. Biotechnol Theory Prac 3: 34-39 (In Russian) 